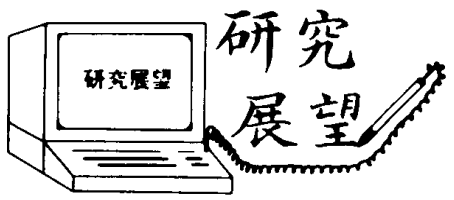

日本機械学会論文集 $(\mathrm{A}$ 編 $)$

75 巻 756 号 $(2009-8)$

\title{
締結・接合・接着部の事故例と 力学対策技術の今後*
}

服部敏雄*1

\section{Accident Examples and It's Mechanical Measures for Joint Structures}

\author{
Toshio HATTORI*2 \\ ${ }^{* 2}$ Faculty of Engineering, Gifu University, \\ 1-1 Yanagito, Gifu-shi, Gifu, 501-1193 Japan
}

Key Words : Mechanical Joints, Bolted Joints, Welded Joints, Adhesive Joints, Fretting Fatigue, Stress Singularity Parameters, CAE

\section{1. 構造強度上の継手部の重要性}

ほとんどの機械, 製品はその生産性，メンテナンス 性などを確保するため，多くの継手部(締結・接合・ 接着部)を有している。ここではこれらの機械・製品 の強度・信頼性上のトラブルの多くがこの継手部で起 こることに注目してみる。

古くは鉄道車軸焼ばめ部のフレッティング疲労, 大 型タンカー船溶接接合部の脆性破壊，その後航空機の リベット締結部の疲労, 新幹線のぞみ号のモー夕締結 ボルトゆるみ落下, HII ロケット用 LE VIIエンジン配 管溶接部破損, 最近ではトレーラハブの破損, 蒸気夕 ービン翼締結部破損, ジェットコースタの車軸ボルト 破損, 電子機器でも瞬間湯沸かし器はんだ接合部の断 線など，例を挙げたらきりがない。

この原因はそもそもこれら継手部での力の流れが複 雑, かつ接触条件など関連因子が多く, 応力解析, 強 度評価が面倒なため, 真正面から力学的検討をせず, 従来からの経験に頼り過ぎてきたこともあると思われ る.たとえば，図 1 に示すような，片持ち梁構造ある いは, 圧力容器を設計しようとした場合, まず.は初等 的な材料力学を用いて片持ち梁ならば，根元の最大応 力 $\sigma=M / Z$, 圧力容器ならば, 周方向応力 $\sigma=P D / 2 t$ を用いて強度評価を行うが，現実にはこのような単純 な構造はほとんど存在しなく, 例えば片持ち梁構造な らば, 根元をねじ締結したり, 締りばめ締結するのが 通常であり，破損は通常この締結部で起こる．また，

* 原稿受付 2009 年 5 月 29 日.

*1 正員, フェロー, 岐阜大学工学部( - 501-1193 吱帛市柳戸 $1-1)$

E-mail : hattori@gifu-u.ac.jp
圧力容器の場合でも一般には鋼板を溶接あるいはリべ ット締結によって製作するのが通常で，破損も同様こ の部位で起こる．平滑部位で破損を起こすような単純 な設計ミスはまずありえない.しかし何もこれは，主 部材，平滑材を主対象とする材料力学解析が役に立た ないと言っているのではない, 基本的な強度評価には 材料力学は不可欠だが, それに加えて重要なことは, 最終的な強度評価にはさらに一歩踏み込んで，これら 継手部に十分注意を払わなければならないということ である。

もちろんこのようなトラブルには, 力学的検討以外 に，生産技術の介在したばらつき，材料科学的な検討 も必要な場合も多々あるが，ここではこの継手部のト ラブルを力学的な面からのみ追求し, 今後の教訓・対 策として紹介する。

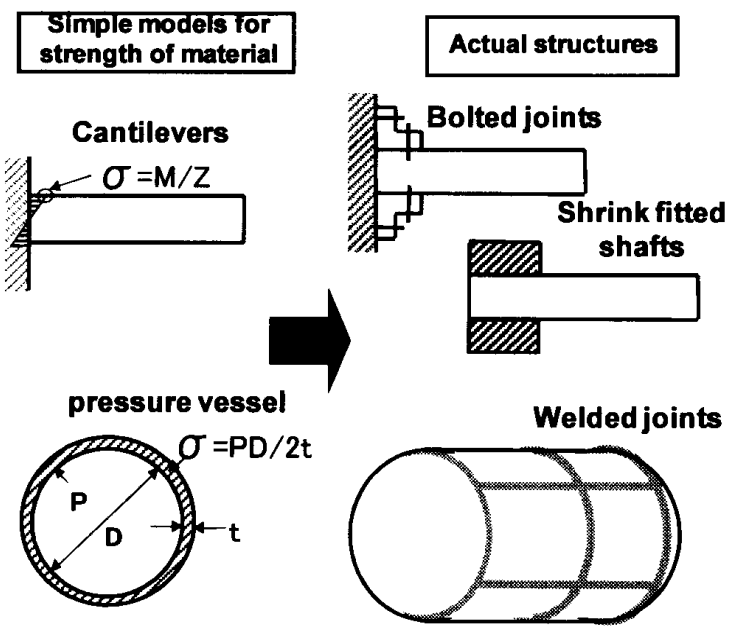

Fig. 1 Material strength models and actual structures 


\section{2.ねじ 締 結 部}

ねじ締結は，分解・再組み立てが可能なこと，小さ な力で大きな締結力が得られることなど, 多くの利点 を有し，機械要素としては最も古い歴史を有しており 古くから多くの解析・研究がなされてきた(1) (13). し かしねじ・ボルトの類はあまりにも身近な沉に力学 的検討が軽んじられている風潮がある，ねじ締結の上 述の利点は，反面一歩間違えると「緩み」，「破壊」と いうトラブルに直結することになり，ねじ軽視は命取 りになることを十分認識することが重要だ。

最近のねじ締結のトラブルの背景に, 異材との締結 の増大がある，例えば軽量化を目的としたアルミ材， FRP 材の使用(1)(2)，半導体をはじめとする電気・電子 機器では絶縁体としてのプラスティック材の締結など である。一般にねじ締結体には図 2 に示す軸方向と， 軸直角方向の 2 種類の負荷が考えられる．まず軸方向 負荷に対しては内力係数の考えが重要となる. 図 3 に ボルト，被締結体ともに鋼の場合と，被締結体にアル
ミを使用した場合の締付け三角形を示す. 外力 $F_{t}$ に 対するボルトの荷重負担分 $F_{b}$ を, 内力係数 $(\Phi=$ $\left.F_{b} / F_{t}\right)$ と言うが, 被締結体をアルミにし，被締結体の 剛性を $1 / 3$ に低下することにより，ボルトの負担荷重 が倍増し，緩み，疲労破壊等を引き起こす可能性が高 まる．また鋼とアルミ，電子機器のように熱膨張係数 の異なる 2 種類の被締結体を複数のボルトで締結した 場合の問題は軸直角方向負荷に対するゆるみである.

ねじ締結体に軸直角方向の負荷が働く場合，図 4 に 示すごとく以下の 2 つの接触面,

すべり面 $\mathrm{A}$ ：両締結体間

すべり面 B：ボルト頭と, 被締結体間

でのすべりが考えられる．荷重の上昇とともに，まず すべり面 A ですべりが発生し，すべり面 B は固着, つまりボルトの頭(あるいはナット)と被締結体は一体 となっており，このすべり変位は全てボルトの弾性曲 げ変形で吸収している．しかしさらに外力を増す(強 制変位を増やす) と，ボルトの弾性曲げ変形がこの強 制変位に追従できなくなりすべり面 Bでもすべるよ

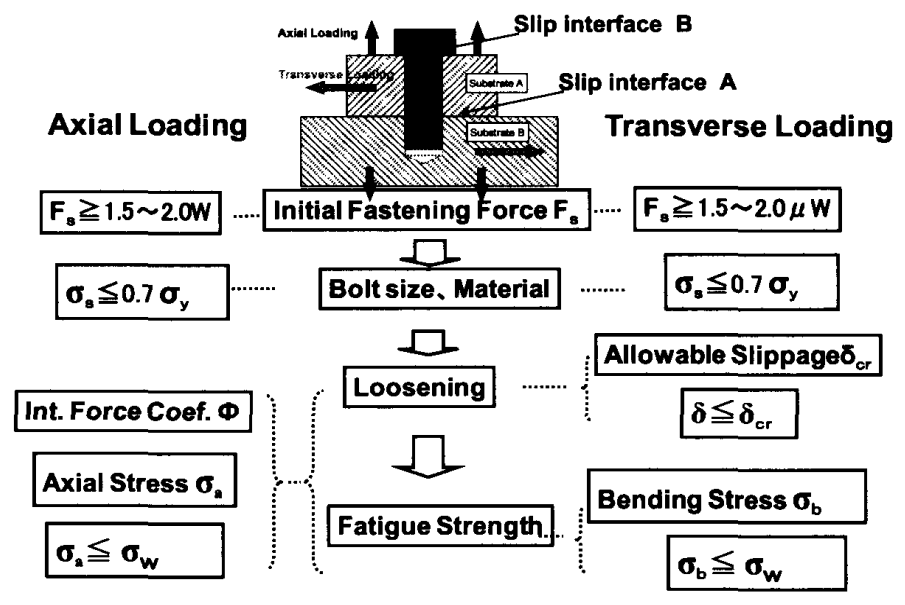

Fig. 2 Design methodology of bolted joints for each loading directions

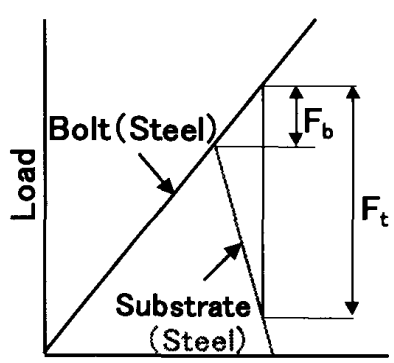

Deformation

(a) Steel substrate

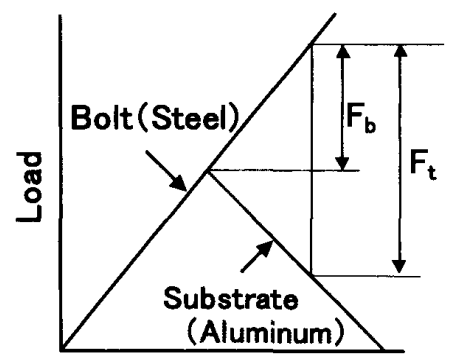

Deformation

(b) Aluminum substrate

Fig. 3 Allotment ratios of bolts depend on the stiffness of substrates 


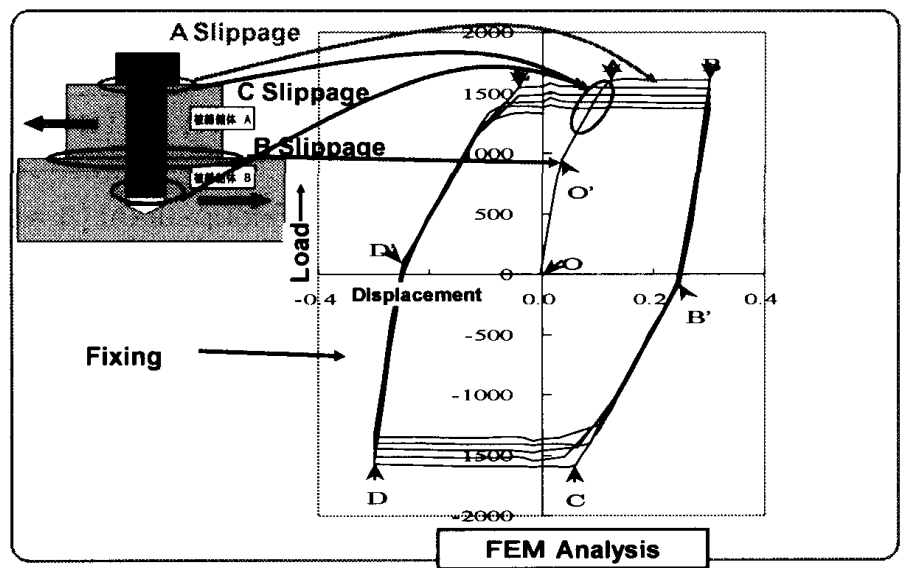

Fig. 4 Slippage and loosening behavior on transverse loadings

うになる。このすべり面 Bですべりが発生し始める と、すべり中にボルト頭に回転のモーメントが与えら れボルト(あるいはナット)に回転ゆるみが発生するこ とも観察，シミュレーションされており，このすべり 面 Bでのすべり発生点がすべり面 A でのゆるみ限界 すべり量 $S_{C R}$ として設計に供されている(2)(3).

教訓・対策としては，まずは，内力係数に基づいた 強度設計の重要性があげられる。そのうえで, 場合に よっては熱変形に対して限界すべり量に着目したゆる み評価等も必要となってくることになる。

\section{3. 接 着 部}

最近の接着剂の利用は目覚しく, 例えば軽量化設計 が要望されている航空機や自動車においては，構造用 接着剤による強度部材の接合が各部で採用される様に なってきている，また，電子・光学機器の組立て，電 子部品の封止(パッケージ)などの分野でも, 精密固定, 無応力締結あるいは工程上の容易さなどの利点から接 着剤利用の拡大は著しい。

しかしこのような現状にもかかわらず，接着接合部 の強度評価が難しいこともあり，トラブル事例は数多 くある.ここでは，電子機器の封止を例に取り上げ, そのトラブルと, 対応としての新しい強度評価法の提 案について述べる.

図 5 に代表的な IC 樹脂封止(プラスチックパッケ ージ)の構造を示す。このパッケージの組立てにあた っては，まずシリコンウエハから切り出した個々のチ ップを接着剤や $\mathrm{Au}-\mathrm{Si}$ 共晶接合などによって金属製 リードフレームのタブ部に固定する，次にチップとリ ードフレームを金線によって電気接続し，これらの周 用をエポキシ樹脂によってモールドする.

パッケージの主要な損傷モードを図 6 に示す.チッ

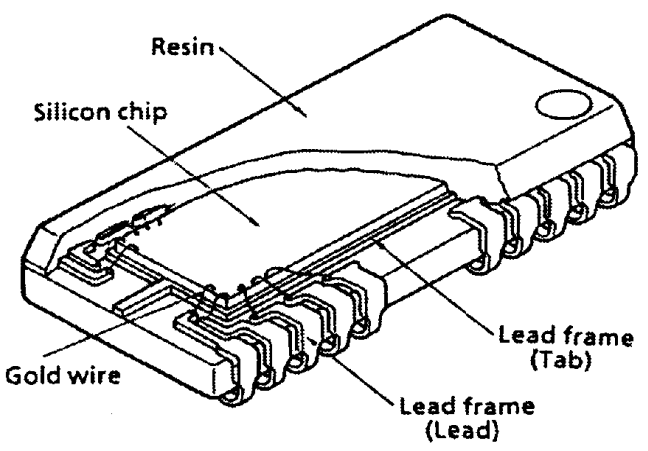

Fig. 5 Structure of IC package

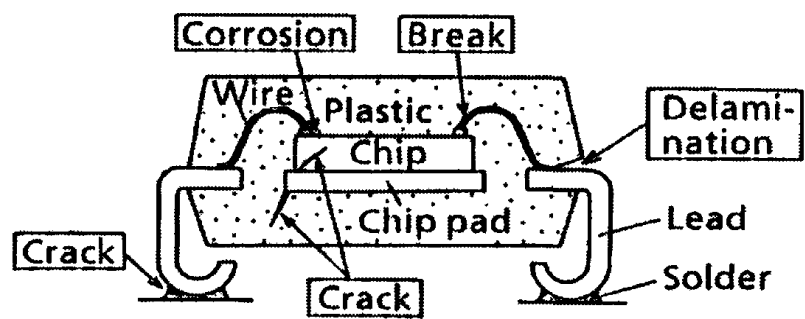

Fig. 6 Failure modes of IC package

プ,リードフレーム，モールド樹脂などは互いに線膨 張係数が異なるため, モールド温度 $\left(170^{\circ} \mathrm{C}\right.$ 前後 $)$ から の冷却や，信頼性試験のための温度サイクル試験など では，パッケージ内部に熱応力が発生する。この熱応 力が原因となって，チップや樹脂，接着界面などに 種々の損傷が発生する，また組立てプロセスなどの外 力や, はんだ付け加熱時のパッケージ内部の蒸気圧な どによっても同様な損傷が発生することがある。これ ら損傷モードの多くには, 界面のはく離が関与してお り，もし界面はく離を完全に防止できるならば，パッ ケージの信頼性は飛躍的に向上する，以下に界面のは く離が関与したいくつかの損傷モードの例について述 
ベる.

\section{（1）アルミ配線腐食}

チップ/樹脂界面のはく離あるいは樹脂中のボイド などによって，チップ表面にすき間が存在すると，こ の部分で水分が結露して水膜を形成し，チップ表面の 微紼 $\mathrm{Al}$ 配線を腐食させる。またりードや金属と樹脂 の界面がはく離すると，外部の水分が容易にチップ表 面に到達するようになり，腐食寿命を低下させる。

(2) チップ割れ(14)

チップ割れは多くの場合，チップをタブに固定する ダイボンディング工程で発生する、リードフレーム材 (42アロイなどの $\mathrm{Fe}-\mathrm{Ni}$ 合金または $\mathrm{Cu}$ 合金)の線膨 張係数はシリコンより大きいため, ダイボンディング 後の冷却過程で熱応力が発生する.チップ, タブの曲 げ剛性が低い場合には，反りによる引張り応力がチッ プ表面に作用して垂直型のチップ割れが生じ，剛性が 高い場合にはチップ端部から水平型の割れが生じるこ とがある.チップ/タブ間に部分的な接着あるいは接 合不良がある場合には，チップに座屈状の変形が発生 し, 樹脂モールド後でもチップ割れを生じることがあ る.

（3）温度サイクル時の樹脂割れ(15)

温度サイクル時の樹脂割れはタブ，リードなどの端 部から発生し，これには通常何らかの界面はく離が関 与している. 代表的なリードフレーム材である 42 ア ロイと $\mathrm{Cu}$ 合金の場合について, 樹脂割れの発生メカ ニズムを図 7 に示す。 42 アロイでは夕ブ/樹脂間, $\mathrm{Cu}$ 合金ではチップ/タブ間の熱膨張差が，界面はく離に よってタブ下端部に応力を集中させる。

（4）リフローはんだ付け時の樹脂割れ

パッケージに使用する樹脂には，わずかではあるが 吸湿する性質がある，現在，電子部品の基板への実装 法として, 基板全体を電子部品とともに加熱するリフ ローはんだ付けが一般となっている。この実装法では パッケージ自体が $200^{\circ} \mathrm{C}$ 以上の高温にさらされるため, 樹脂が吸湿している場合，水分が気化してタブ/樹脂 などの界面に高い蒸気圧が作用する，この蒸気圧は図 8 に示すように界面をはく離させ，さらに樹脂の割れ を引き起こすことがある(16). 図 9 はパッケージ加熱 開始後の蒸気圧の変化を, 水分拡散・変形シミュレー ションによって求めた例(16) である. 40 秒後のパッケ

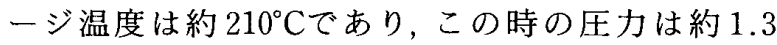
$\mathrm{MPa} に も$ 達している.これらのトラブルを防止する ためには，各接着界面のはく離強度の正確な評価が不 可欠である．接着界面の強度評価で最も困難な点は， はく離発生の起点となる接着端では材料および形状の

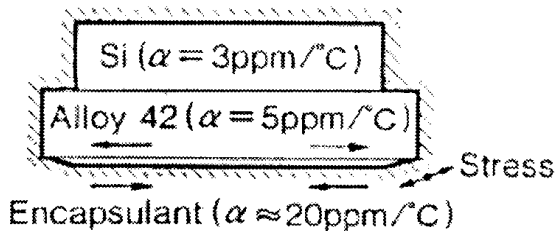

(a) Alloy 42 lead frame

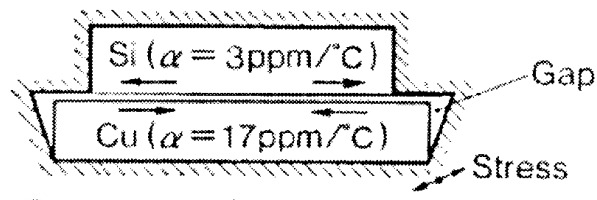

Encapsulant ( $\alpha \approx 200 p m / \mathrm{C}$ )

(b) Copper lead frame

Fig. 7 Mechanisms of resin cracking ( $\alpha$ : Thermal expansion coefficient)

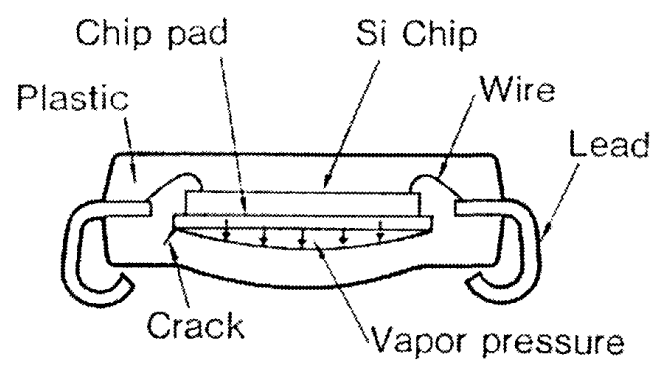

Fig. 8 Resin cracking caused by steam pressure

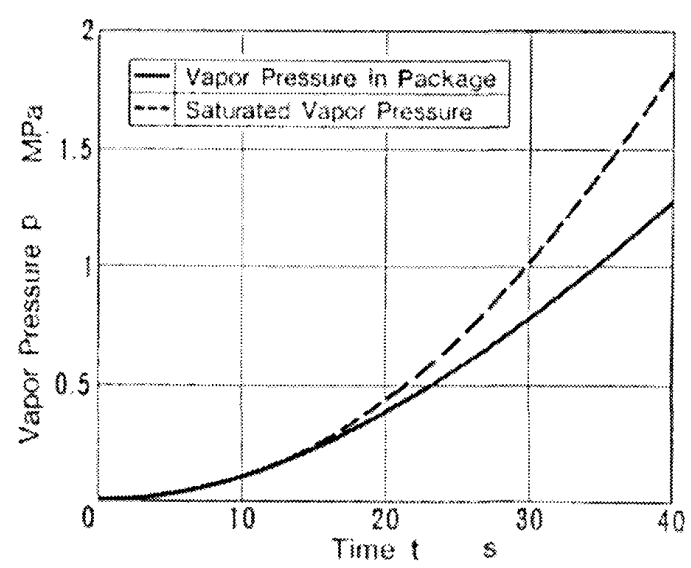

Fig. 9 Steam pressure in soldering process

不連続のため, 応力の特異場となり, 応力値のみでは 高精度な評価ができないことである。そこで過去この 応力特異場を近似的に表現する二つの応力特異場パラ メータを用いて接着界面の強度評価をする方法が提案 されてきた (17) 〜22). 例えば, 図 10 に示す接着端の場 合, この近傍の応力分布が近似的に 
$\tau(r)=H / r^{\lambda}$

$\tau(r)$ : 応力 $\mathrm{MPa}$

$r:$ 特異点からの距離 $\mathrm{mm}$

$H:$ 応力特異場の強さ

$\lambda:$ 特異性の指数

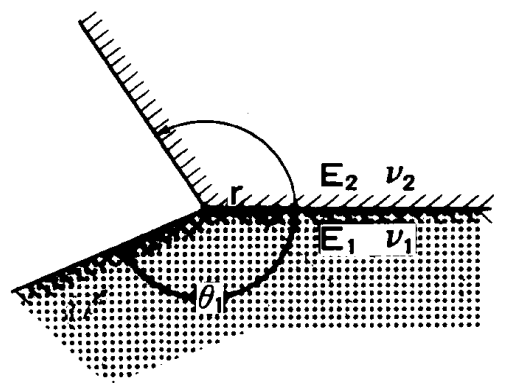

Fig. 10 Geometry of bonding edge

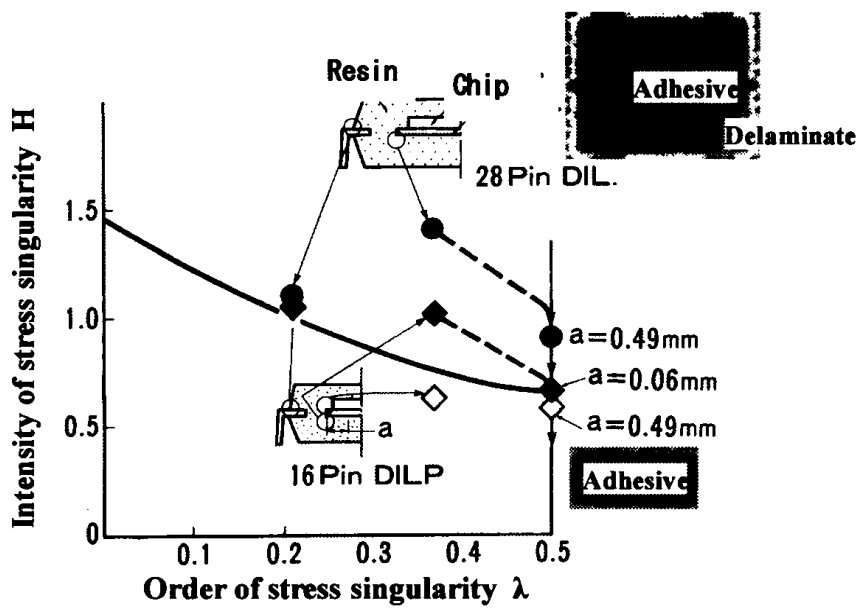

Fig. 11 Adhesive strength evaluation using stress singularity parameters

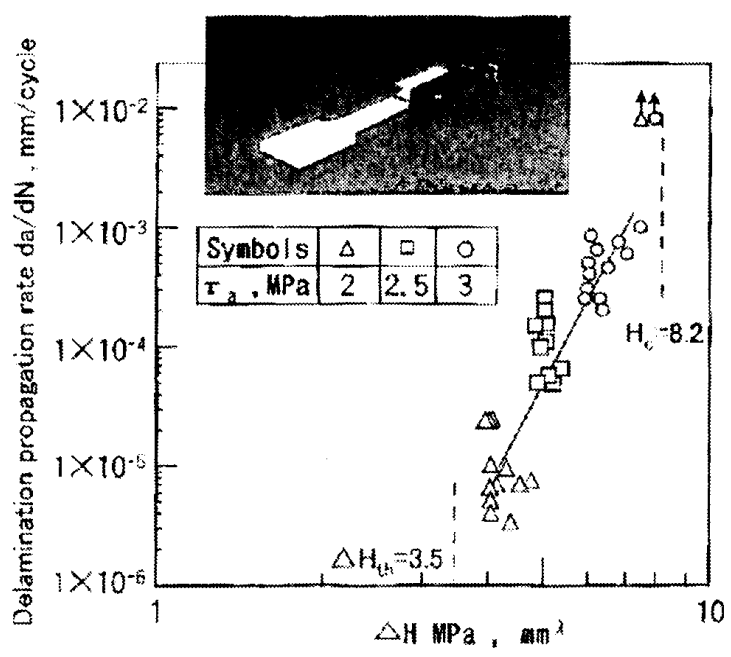

Fig. 12 Delamination rate evaluation using stress singularity parameters

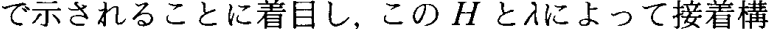
造の強度を評価する方法を提案し, 種々適用を行って きた(20)(21)。この方法をパッケージモールド後の降温 過程でのはく離発生を予測した結果を図11に示す。 16 ピン及び 28 ピンのいずれのパッケージでも, タブ 下面の接着端にはく離が発生する。しかしこのはく離 は, 16 ピンパッケージの場合，はく離はほとんど進展 しないで停止すると予測されるが, 26 ピンの場合かな りの領域まではく離が進展すると予測される。これら の予測結果は, 同図の超音波観察の結果ともよく一致 しており，この評価法の妥当性が確認できる.

この手法は, 破壊力学でのき裂進展評価 $(\triangle K-$ $d a / d N)$ 同様に, 接着界面の熱サイクルあるいは絽返 し負荷下でのはく離進展の評価 $(\triangle H-d a / d N$; 図 12 参照)に供されるようになり，接着構造物機器の寿命 評価も可能となった (22).

\section{4. 接 触 端 部}

接触端部も接着端部と同様応力特異場となってお り, 非常に低い応力の繰返しで, 接触端に微小き裂が 発生することがある。これをフレッティング疲労と呼 び過去解析的・実験的な研究が種々行われてき た(23) (31)。例えば，図 13 に示すような，焼きばめ軸継 手, タービン発電機コイルウエッジ部, ターボ機械動 翼はめ込部などである。ここではタービン発電機コイ ルウエッジ部のトラブルをとりあげ，その状況と対応 について示す(27).

タービン発電機は図 14 に示すごとく, ローターと ステーターより成り，ローターの断面は, 図 15 のごと く多数のスロットが形成されており，ここにコイルを 入れて電極を構成している．ここでこのスロット内で コイルが遠心力で飛び出ないようにウェッジで押さえ られている．この場合ウエッジは軸方向に多数に分断 され，スロットは軸方向に一体となっているため，必

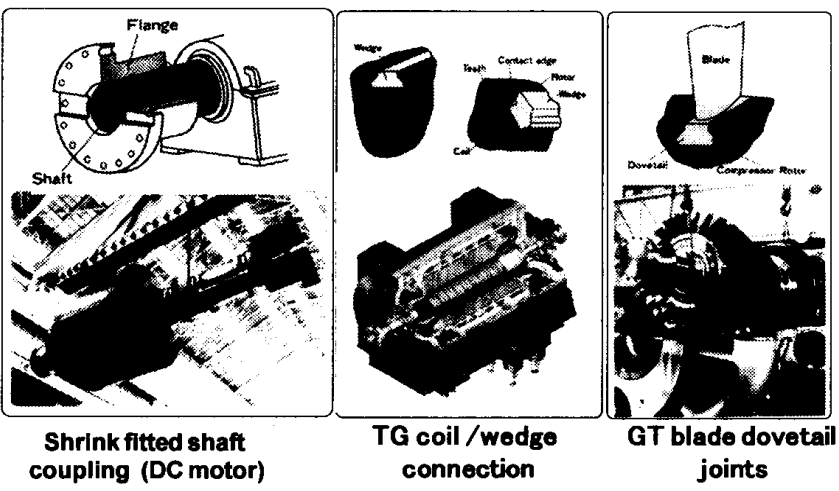

Fig. 13 Failure examples of fretting fatigue 


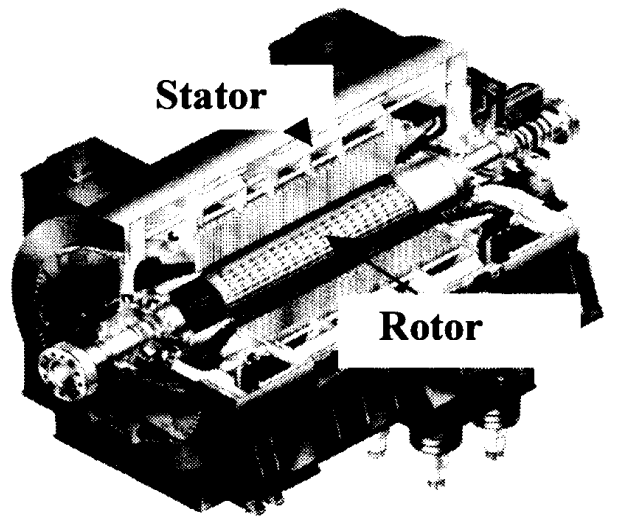

Fig. 14 Turbine generator

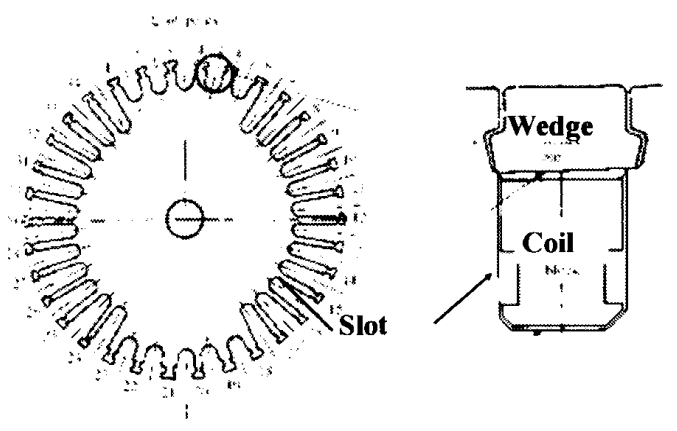

Fig. 15 Cross section of TG rotor ${ }^{(27)}$

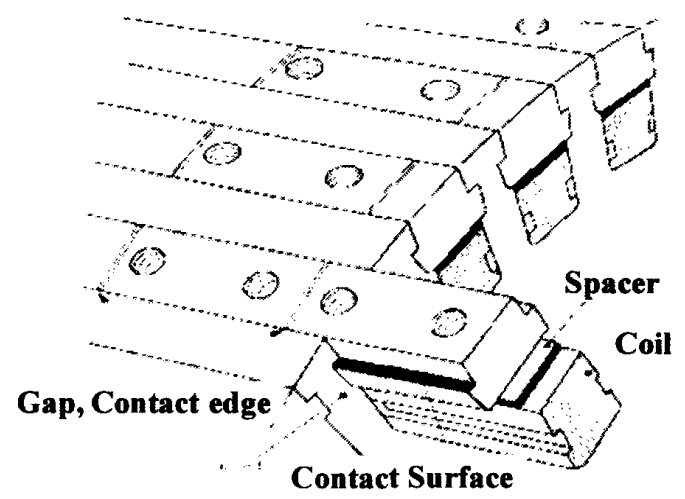

Fig. 16 Gap between slot and wedge $e^{(27)}$

ず図16のように接触端，ギャップが存在し，ローター が自重で撓んだ状態で回転するとローターの一回転毎 にこの接触端で相対的なすべり及びせん断力の集中が 発生することになる。近年タービン発電機の大容量化 に伴いローター長が伸びると，この相対すべり，せん 断力の集中も増大し, 上記フレッティング疲労により, ローターが破断するという事故が 1976 年英国で起こ った。破面は図 17,18 に示すように，ダミースロット の接触端部に微小き裂が発生し, 最初非常にゅっくり

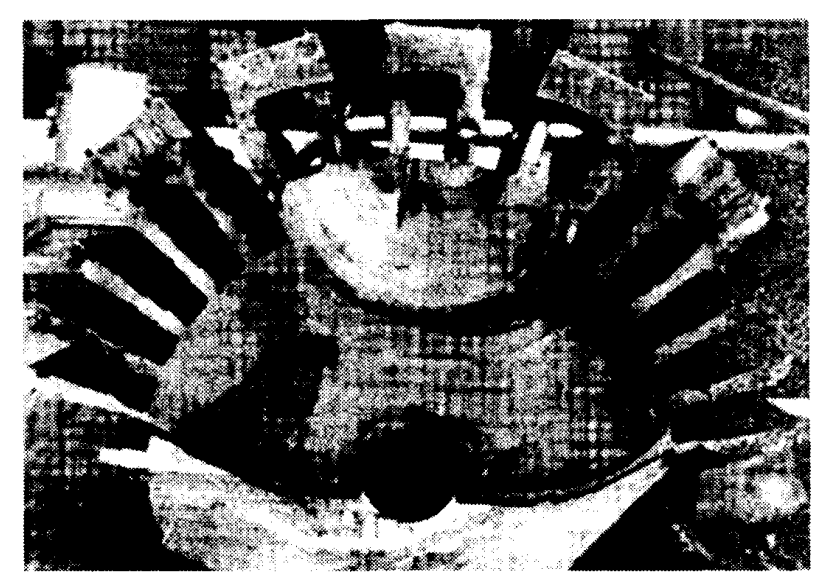

Fig. 17 Fatigue failure surface of TG rotor

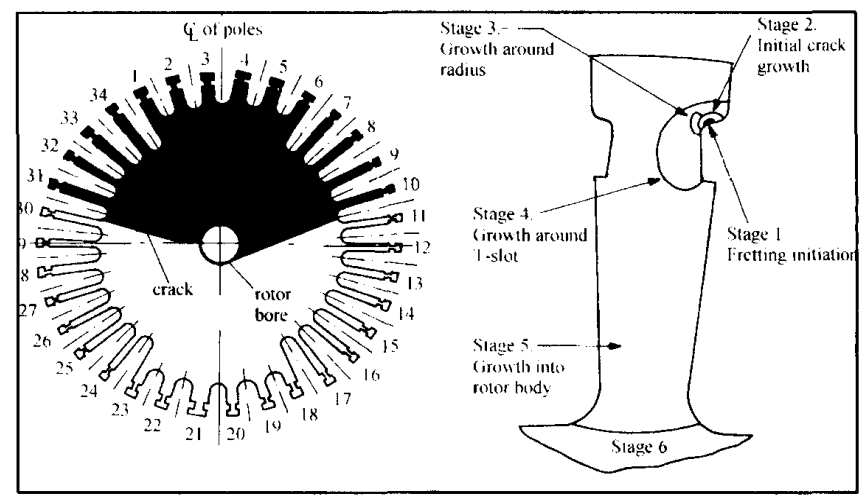

Fig. 18 Fretting fatigue crack propagation process in TG rotor

進展し, 長い時間をかけて進展し破断に至るというフ レッティング特有の経過を示している.

この種のフレッティング誘起疲労損傷を考慮した強 度設計には，この微小き裂の発生, 進展の予測が不可 欠である。従来は，この接触条件下の応力解析が困難 であったこと，フレッティング疲労強度の低下は単に 応力のみでなく, 酸化などの金属学的, 化学的な因子 が重要視されていたため, 近似モデルを用いた疲労試 験デー夕に基づいて強度設計されてきたが, 最近では, 接触条件下の応力解析技術の進歩(28), 破壊力学解析, 応力特異場解析の進歩(24)(29) (31) によって，応力のみか ら相当精度よく強度予測できるようになった。ここで はこれらフレッティング疲労の全プロセスを考慮した 強度評価法について述べる. 図 19 にそのモデルを示 すが，そもそも接触端は応力が集中して，き裂は発生 し易いが，この発生した微小き裂はこの接触端に働く 高い接触面圧のために開口しづらく進展しないままあ る程度の寿命を費やすことになる。しかし、この接触 端部にフレッティング摩耗が進展してくるとこの高い 面压集中が緩和され，この微小き裂も開口し易くなり 


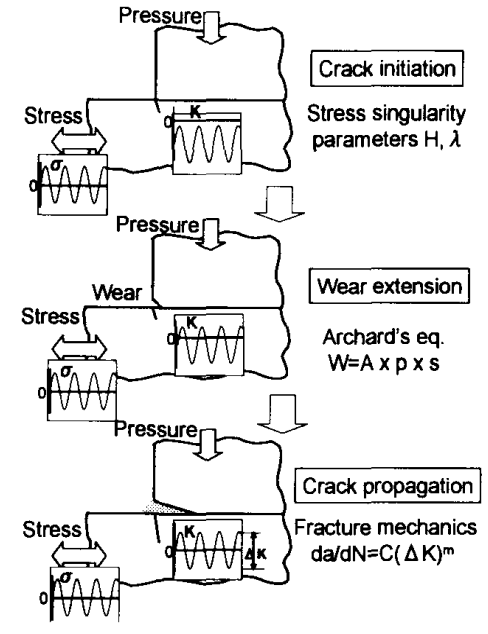

Fig. 19 Mechanisms and processes of fretting fatigue

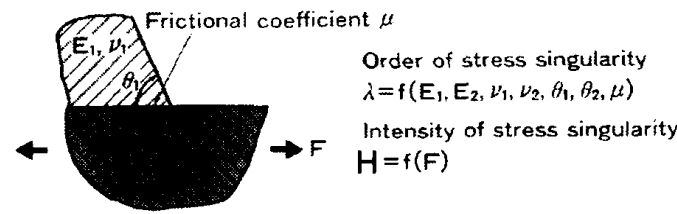

Fig. 20 Geometry of contact edge and stress singularity parameter

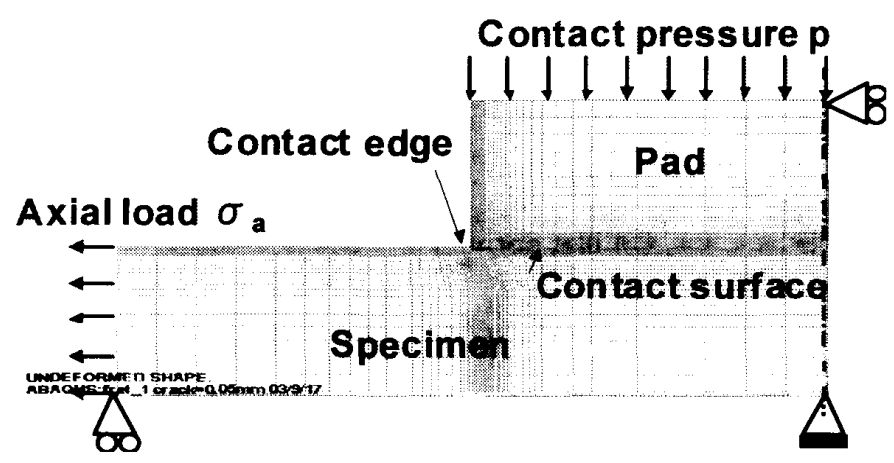

Fig. 21 Contact model for analyze initiation of fretting fatigue crack

いよいよ進展し始めることになる。

そこで以下に，応力特異場パラメータを用いたフレ ッティング微小き裂の発生予測, それを用いた接触端 部構造の最適化について述べる.

一般に図 20 に示すような接触端近傍の応力分布は, 前述の接着端と同様, 二つの応力特異場パラメータ $H$ と入で表わされる. 特異性の指数入は, 各々の材料の 弾性係数, 接触端の角度, 摩擦係数によって决まる. 図 21 の単純なフレッティングモデルの解析例を図 22 に示す。また接触端角度それぞれ $90^{\circ}, 80^{\circ}, 60^{\circ}$ 及び $45^{\circ}$ の場合の接触端近傍の応力分布を式 (1)にベスト

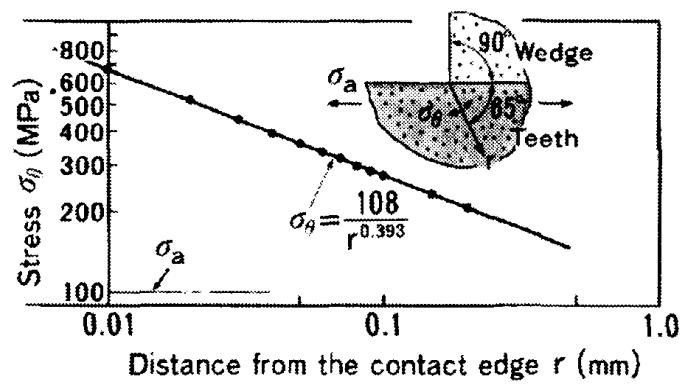

(a) Wedge angle $\theta=90^{\circ}$

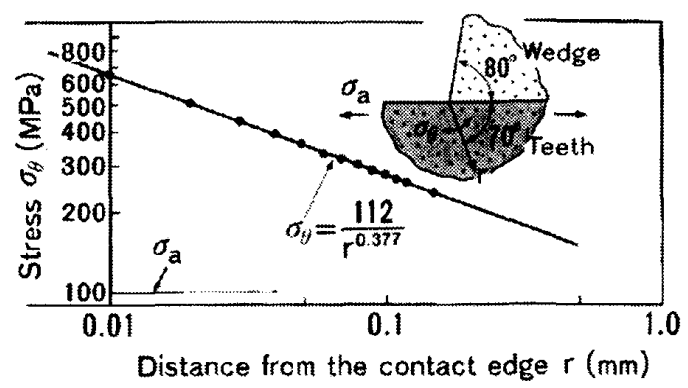

(b) Wedge angle $\theta=80^{\circ}$

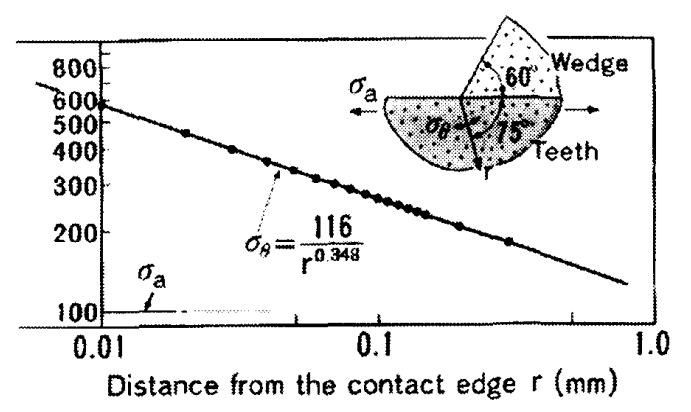

(c) Wedge angle $\theta=60^{\circ}$

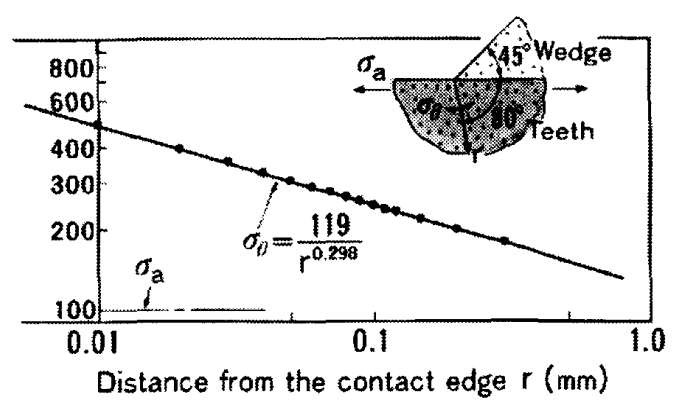

(d) Wedge angle $\theta=45^{\circ}$

Fig. 22 Stress distributions near contact edge

フィットして求めた $H$ と $\lambda$ を図中に示す。このよう にして求めた応力特異場パラメータを，素材 $\left(\mathrm{Ni}^{-}\right.$ $\mathrm{Mo}-\mathrm{V}$ 鋼 $)$ の疲労強度データベース $\left(\sigma_{w 0}\right.$ など $)$, 破壊 力学データベース $\left(\Delta K_{t h}\right.$ など $)$ よ求めたき裂発生限 界基準(図 23) と比較することにより，フレッティング き裂発生強度が，図 24 のごとく求まる。この図から， 接触端角度を $\pi / 3$ 以下にするとフレッティング疲労 


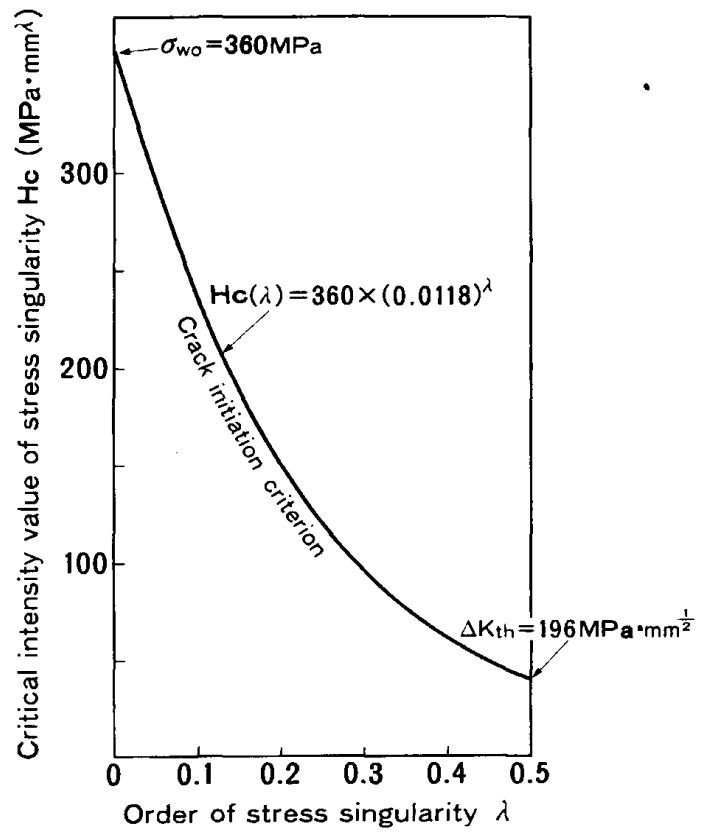

Fig. 23 Crack initiation criterion using stress singularity parameters

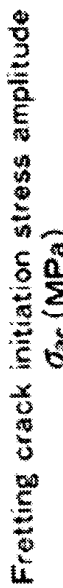

Fig. 24 Relation between fretting fatigue crack initiation strength and contact edge angle

き裂発生強度を高めることができることが分かる。従 ってフレッティング疲労強度の観点から言えば, 接触 端の形状は, 図 25 の左側の形状よりも右側の形状が 適切であることが分かる.この見方は先述の接着端で も同様であるが,このような応力特異場部位は，図 26 に示すように，むしろ一体化されたモデルとして見た ほうが奏用的で分かり易く, 容易に対策形状が思いつ くことになる.

次にこの発生した微小き裂の, 摩耗の進行に伴いな がらの進展を予測する必要があるが, 摩耗の進行に関 してはArchardの式，き裂の進展に関しては破壊力 学を用いて詳細に解析した例(32) があるのでご参考願

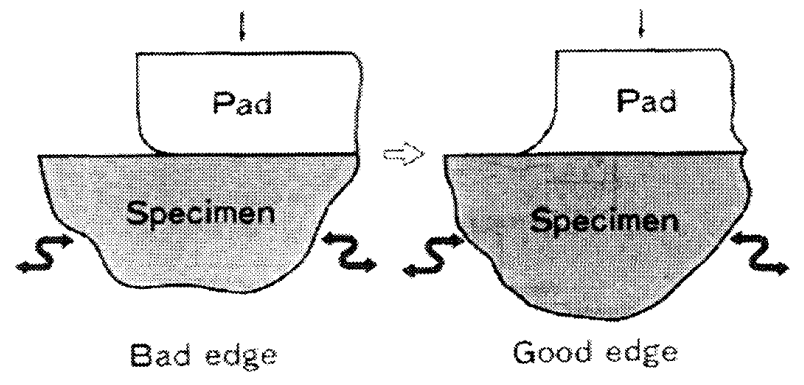

Fig. 25 Recommendation of contact edge shapes

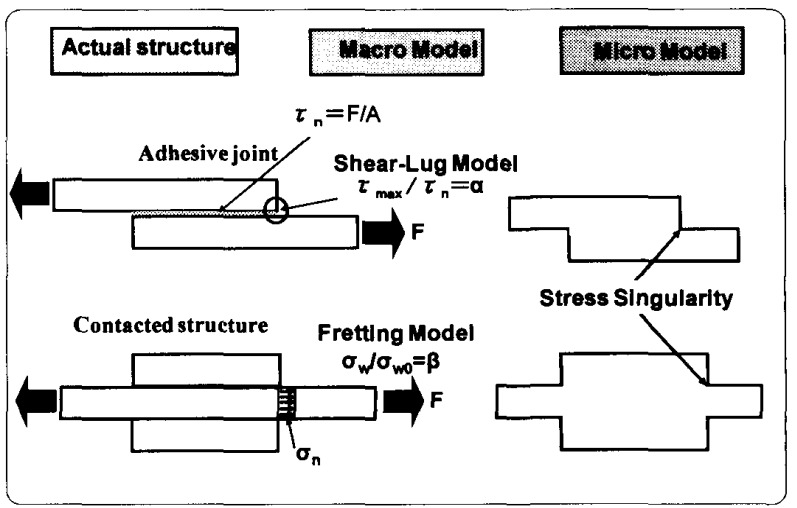

Fig. 26 Imagination models for fatigue strength evaluation of adhesive or contacted structures

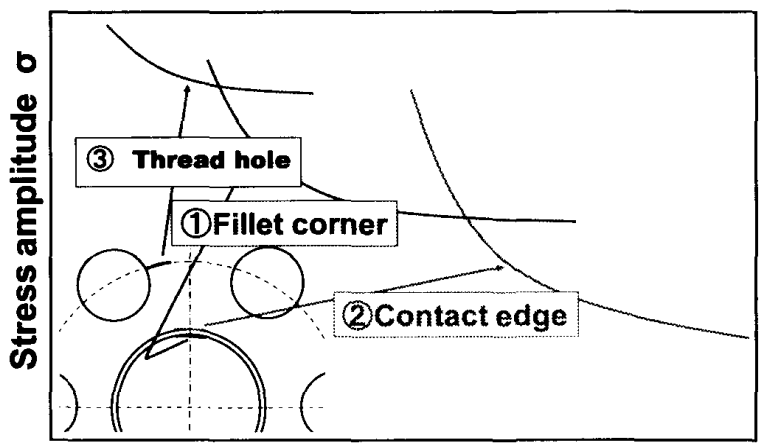

Number of cycles $\mathbf{N}$

Fig. 27 Fatigue strength for each portion in hub joint structure

いたい，結果的には，超長寿命の果てに，フレッティ ング疲労強度は, 先述の接触端でのき裂発生強度にま で下がることになり，実験室的に得られる $10^{7}$ 程度の 疲労強度を用いて製品の強度設計を行うと失敗をする こととなる．その例が先述のタービン発電機ロータ破 損, 最近のトレーラハブ, ゆりかもめハブ, ジェット コース夕車軸等の輸送機器の締結部の破損と考えられ る.図 $27 に$ にトレーラの破損例ハブ締結部位を示す. 負荷が大きい場合は(3)のねじ孔部をつなぐ部位の静的 破断が考えられるが，負荷が下がり高繰返し数領域に 
なるに従って, 応力集中の高い(1)の段差部,さらに超 高繰返し数領域になると,フレッティング疲労による (2)の接触端部での破損が考えられる。これを $S-N$ 曲 線で示すと図 27 の如くなる. 製品の品質保証試験と して工場内で, 通常の疲労強度確認として行われる $10^{7}$ 程度の繰返し数領域で確認したのみでは, 実際の 顧客でのそれ以上での稼動繰返し数領域での摩耗を伴 ったフレッティング疲労強度レベルを充分把握したこ とにはならず，顧客の使用中に事故につながる可能性 がある。

\section{5. $\mathrm{CAD} / \mathrm{CAE}$ 一気通貫設計ツールの開発}

これまで, 締結・接合部の力学設計に関わる問題点 とそれを解決する個別技術を述べてきたが，これから の産業界での現場設計者の重要な仕事は, これら高度 な個別技術を正確に使いこなして頂くことにある，常 日頃幅広い技術分野をレパートリーとしておられる機 械設計者として，これらを一切見落とし無くカバーす ることは至難の業とも考えられるゅえ, 誰が設計して も上記要素技術を見落とさないような規格・基準化, さらにはこれらの基準の設計ツールへの組込みが必要 となる。例えばフレッティング疲労に関しては，以前 機械学会機械材料・材料加工部門内にフレッティング 波労標準試験法作成分科会を設立 (武藤委員長) し, 世 界に先駆けて学会標準規格「JSME S 015 フレッテ イング疲労試験方法 (33)を出版し, 設計技術者の設計 精度向上に大いに貢献している. 一方 IT 活用設計技 術の目覚しい進展の中にあって構造設計は立派なソル バー(FEM 解析ソフト)があればよいんだという安易 な納得がある. 確かに最近非線形, 接触, 衝撃等ほと んどの問題に対応できるソルバーの開発は目覚しい が,それよりさらに重要なことは,

(1)この解析に用いる締結・接合部モデルの正しい作 成。

(2)解析結果に基づいた沉用的強度評価法の確立.

(3)これらを図 28 の如く結びつけた一気通貫 CAE 設計システムの構築。

である，以下これらを具体的に説明する。

\section{$5 \cdot 1$ 締結・接合部のモデル化(等価剛性, 等価減衰} 率）勿論一体成形(削り出し)で製作された機械・ 機器ならば上記障害は無くFEM 解析で十分正しい解 が得られるが, ほとんどの機械・機器はその組立て性, 解体性の要求から多くの締結・接合部を有しておりこ の締結・接合部をどうモデル化するかが重要となる。 これは一見ささいな問題ではないかと錯覚を受ける が，ほとんどの構造物が材料力学で言う “不静定問

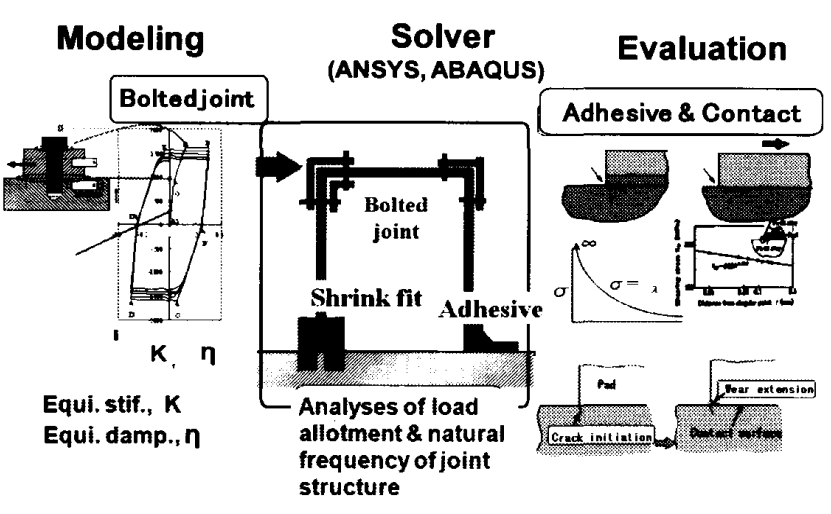

Fig. 28 Modeling/Analysis/Evaluation unified CAE systems and necessary databases for each process

題”であることから重大なこととなる．例えば図 28 中央に示す 3 本の柱・梁を 3 種類の締結方法で組み立 てたとする.この構造物に外力が加わった場合の各梁 に加わる応力を計算しょうとする場合実はこの 3 種類 の締結部の等価剛性が分からないと各柱・梁に加わる 荷重分担が予測できないのである。つまり剛性の高い 締結部，柱・梁には大きな荷重分担を引き受けさせら れ，剛性の低い締結部，柱・梁は遊ぶことになる，従 つてある締結部の等価剛性を見誤ると，その締結部の みでなく構造全体の荷重分担を見誤ることとなりせっ かく立派なりルバーを使っても解析者が正しい等価剛 性, 等価減衰率を入力しなければ正確な解は得られな い.それならばこの締結・接合部を実機のまま忠実に モデル化すればいいのではないかという考えもある が, 一般に機械・機器は何十, 何百というねじ締結, はめあい部を多用しており，これらを全て接触問題で 解析するのは現実的に不可能であり, コストパフォー マンスを考えたら意味の無いこととなる.

$5 \cdot 2$ 解析結果の表示と強度評価 通常 FEM 解 析の結果表示は応力分布の等高線表示が主で, 強度評 価は単純にこの等高線の最大応力値を使って疲労強度 評価等を行っているのが現状である. しかし一般に最 大応力が発生する複雑形状の表面の節点応力は積分点 㐫力からの外挿が一番難しいところであり, 結果的に 多くの費用と労力を使いながら一番誤差の大きい応力 值を用いて強度評価している事になる。従ってせっか くの解析結果を $100 \%$ 使い切るためには, 応力分布を 等高線表示のみでなく最大応力勾配方向に沿っての応 力分布グラフ表示を自動化し，これを用いて強度評価 する設計システムを構築する必要がある。この最も象 徵的な例が接着端, 接触端部 (焼嵌め端部)の応力特異 場領域の解析結果表示, 強度評価である。この場合に 
Table 1 Organization/role map of committee RCD 356 "Construction of modeling, analyzing, evaluation $\mathrm{CAE}$ system on joint structure"

\begin{tabular}{|c|c|c|c|c|}
\hline \multirow{2}{*}{ WG } & \multicolumn{2}{|c|}{ Databases for CAE } & \multirow{2}{*}{$\begin{array}{c}\text { Standardization } \\
\text { of test }\end{array}$} & \multirow{2}{*}{$\begin{array}{c}\text { Chair of oach } \\
\text { WG }\end{array}$} \\
\hline & Modeling (Pro.) & Evaluation(Post) & & \\
\hline Bolted joint & 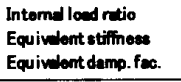 & $\begin{array}{l}\text { Fatioue strousth } \\
\text { Loosoning }\end{array}$ & $\begin{array}{l}\text { Axial louding } \\
\text { Transveres loading } \\
\text { Theomel eyclo }\end{array}$ & $\begin{array}{l}\text { T. Kagivada } \\
\text { S. Izumi }\end{array}$ \\
\hline Adhosive & $\begin{array}{l}\text { Elements for achaivo } \\
\text { interface \& bond odze } \\
\text { Properties of matorid }\end{array}$ & $\begin{array}{l}\text { Multi-wiel stroses } \\
\text { Surfece oneroy } \\
\text { Stroses singulerity } \\
\text { Fracture mochenics }\end{array}$ & $\begin{array}{l}\text { Standwredizod TP } \\
\text { Lop, Butt, Teer, } \\
\text { Dolemination } \\
\text { da/dN } \\
\text { Thermal eyclo }\end{array}$ & $\begin{array}{l}\text { C. Satou } \\
\text { M. Imase }\end{array}$ \\
\hline Frotting & $\begin{array}{l}\text { Contact problem } \\
\text { Explicit/mplicit od } \\
\text { ABAQUS, DYNA }\end{array}$ & $\begin{array}{l}\text { Creck initiation } \\
\text { Woar } \\
\text { Creck propeption }\end{array}$ & JSME S015 & $\begin{array}{l}\text { M. Kubots } \\
\text { N. Nishimers }\end{array}$ \\
\hline
\end{tabular}

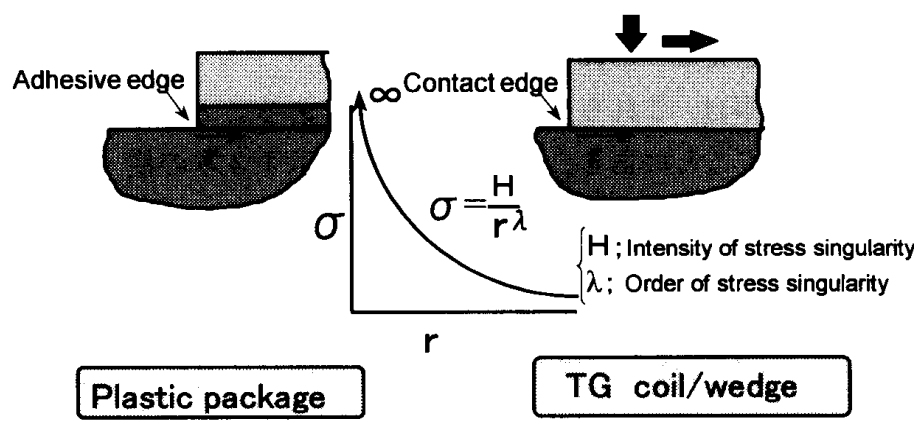

Fig. 29 Stress distributions near adhesive or contact edges and strength evaluation using stress singularity parameters

は図 29 に示すごとく端部で応力は無限大となる応力 分布をしており FEM の最小要素寸法を小さくすれば するほど最大応力は大きくなり従来の方法では汎用的 な強度評価が出来ない. そこでこの応力分布が 2 つの 応力特異場パラメータ,つまり応力特異場の強さ $H$ と，特異性の指数入で表示できる事に着目し，この 2 つのパラメータを応力分布からベストフィット自動算 出して強度評価する方法が必要となる。

これらの技術は，現在産業界での厳しいグローバル 競争の時代に，世界に先駆けて標準化を勝ち取るべき 戦略上重要な技術と考えている。

これを目標に，過去 2006 年 4 月〜2009 年 3 月まで， 機械学会機械材料・材料加工部門の中に, RSCD 356 「締結・接合・接着部の CAE 用モデリング及び 評価技術の構築」分科会を設立して, 表 1 の 3 つ WGに分けて，モデリング(プリ)，表示・評価(ポス ト）に分けて活動を進めてきた。

現在これらの要素技術成果にさらに幅広いものつく り現場の設計・生産技術・品質保証・保全の技術者の 意見も入れた汎用ツールに仕上げるべく，この 2009 年 4 月〜2011 年 3 月までの計画で, RC-D 6 「締結・ 接合・接着部の CAEモデリング・解析・評価システ
厶構築研究分科会」が設立され，さらに実用のフェ一 ズに向けた分科会活動が展開が続けられている．当分 科会では引き続き新しい研究委員, 企業委員の参加依 頼を続けているので，ご賛同頂ける方は是非お申し出 願いたい.

\section{文献}

(1) NIKKEI, New Materials, $(1992,10,5)$, p. 8.

(2) Izumi, S., Three-dimensional Finite Element Analysis on Tightening and Loosening Mechanism of Bolted Joint, Transactions of the Japanese Society of Mechanical Engineers, Series A, Vol.71, No.702 (2005), pp. 204-212.

(3) Nishimura, N., Hattori, T. and Yamashita, M., Self Loosening Behavior of Metal Thread Joints under Transverse Cyclic Loading, Key Engineering Materials, Vol. 340-341 (2007) pp. 1467-1472.

(4) Yamamoto, A., Theory and Design of Bolt Joints (in Japanese), (1977), p. 30, Yokendo.

(5) Yoshimoto, I., Points for Design of Bolt Joints (in Japanese), (1992), p. 177, Japanese Standards Association.

(6) Editorial board of handbook of joint technique, Handbook of Joint Technique (in Japanese), (1994), p.615, Industrial service center.

( 7 ) VDI 2230, Systematische Berehnuy Hochbean Spruchter Schraubenverbindg, (1974).

(8) Fukuoka, T., Finite Element Simulation of Mechanical 
Behaviors and Seal Performance of Oil Seal Plug, Transactions of the Japan Society of Mechanical Engi neers, Series A, Vol.64, No. 625 (1998), pp. 2395-2401.

(9) Kim, J. G., Finite Element Modeling and Experimental Verification of the Structures with Bolted Joints, Transactions of the Korea Society of Mechanical Engineers, Vol. 20, No. 6 (1996), pp. 1854-1860.

(10) Hurrell, P. R., Good Practice in Modelling of Pressure Vessel Bolted Joints for Stress and Fatigue Analysis, ASME PVP, Vol. 405 (2000), pp. 123-130.

(11) Montgomery, J., Methods for Modeling Bolts in the Bolted Joint, ANSYS 2002 Conference, (2002).

(12) Rutman, A. and Kogan, J. B., Software takes the load off joint modeling, Machine Design, Vol.70, No. 6 (1998), pp. 79-87.

(13) Naruse, T., Simple Modelling and Strength Evaluation Methods for Bolt Joints Using Shell Elements and Beam Elements ((1) Modelling Method), Transac. tions of the Japan Society of Mechanical Engineers, Series A, Vol. 73, No. 728 (2007), pp. 522-530.

(14) VanKessel, C. G. M., IEEE Trans. Comp., Hybrids, Manuf. Technol., CHMT-6 (1983), pp. 414-420.

(15) Nishimura, A., IEEE Trans. Comp., Hybrids, Manuf. Technol., Vol. 12 (1989), pp. 639-645.

(16) Fukuzawa, I., Proc. 23rd Int. Reliability Physics Symp. (1985), pp. 192-199.

(17) Ioka, S., Kubo, S., Ohji, K. and Kishimoto, J., JSME International Journal, Vol. 39, No.2 (1996), pp. 197203.

(18) Kubo, S., Kuchinishi, M., Sakagami, T. and Ioka, S., Internationl Journal of Appllied Electromagnetics and Mechanics, Vol. 15 (2001), pp. 261-267.

(19) Koguchi, H., Muramoto, T. and Ihara, I., JSME International Journal, Vol. 42, No. 1 (1999), pp. 80-89.

(20) Hattori, T., A stress singularity parameter approach for evaluating adhesive strength, Transactions of the Japan Society of Mechanical Engineers, Series A, Vol. 54, No. 499 (1988), pp. 597-603.

(21) Hattori, T., A stress singularity parameter approach for evaluating the adhesive strength of single lap joints, Transactions of the Japan Society of Mechanical Engineers, Series A, Vol.56, No. 523 (1990), pp. 618623.

(22) Iwasa, M. and Hattori, T., New application of fracture mechanics, Journal of Material Science, Vol. 39, No. 439 (1990), pp. 463-469.

(23) Mutoh, Y., JSME International Journal, Vol. 38, No. 4 (1995), pp. 405-415.

(24) Xu, J.-Q., Mutoh, Y., Shirai, S. and Kondoh, K., Journal of Japan Society of Materials Science (in Japanese), Vol. 52, No. 1 (2003), pp. 69-74.

(25) Hirakawa, K. and Kubota, M., Proceeding of Instantaneous Mechanical Engineers, Vol. 215-F (2001), pp. 7382.

(26) Kondoh, Y., Journal of Japan Society of Materials Science (in Japanese), Vol. 51, No. 9 (2002), pp. 10171022.

(27) Suresh, S., Fatigue of Materials, 2nd ed., (1998), Cambridge Univ. Press.

(28) Okamoto, N. and Nakazawa, M., International Journal of Numerical Methods in Engineering, Vol. 14 (1979), pp. 377-385.

(29) Hattori, T., Fretting fatigue analysis using fracture mechanics, Transactions of the Japan Society of Mechanical Engineers, Series A, Vol. 53, No. 492 (1987), pp. 1500-1507.

(30) Hattori, T. and Nakamura, M., Fretting Fatigue Evaluation using Stress Singularity Parameters at Contact Edges, Fretting Fatigue, ESIS 18, (1994), pp. 453-460.

(31) Hattori, T., Nakamura, M. and Watanabe, T., Fretting Fatigue Life Simulation using Stress Singularity Parameters and Fracture Mechanics, Developments in Fracture Mechanics for the New Century ASMS, (2001), pp. 110-117.

(32) Hattori, T. and Watanabe, T., Fretting Fatigue Strength Estimation Considering the Fretting Wear Process, Tribology International, Vol. 39 (2006) pp. 1100-1105.

(33) Mutoh, Y., Standardization of fretting fatigue test, JSME S 015 (2002), JSME. 